\title{
International Registration of Cultivar Names for Salix L. (Willow) in 2016-20
}

\author{
Yulia A. Kuzovkina \\ Department of Plant Science and Landscape Architecture, Unit-4067, \\ University of Connecticut, Storrs, CT 06269-4067
}

\section{Lorenzo Vietto}

Council for Agricultural Research and Economics, Research Centre for Forestry and Wood Strada Frassineto 3515033 Casale Monferrato (AL), Italy

Additional index words. Salix, willow, breeding, cultivars, germplasm resources

\begin{abstract}
The International Poplar Commission, FAO UN, was appointed to serve as the International Cultivar Registration Authority for the genus Salix in 2013 (Kuzovkina and Vietto, 2014). Eight hundred and fifty-four cultivar epithets were included in the Checklist for Cultivars of Salix (Willow) to provide the baseline for the formal registration of new cultivars epithets (Kuzovkina, 2015a, 2015b). Twenty-six new cultivar epithets have been registered since 2016 and included in the International Register of Cultivars of Salix (Willow) (2020).
\end{abstract}

The following 11 cultivars were registered 20 July 2020 by Michael Dodge; Vermont Willow Nursery, VT (Vermont Willow Nursery, 2020).

'Arnold Select'. A vigorous male clone of $S$. miyabeana Seemen. It is a large shrub that is ornamental in all seasons, colorful in winter, with showy male catkins in very early spring and attractive foliage all summer. Its coppiced stems are unusually dark redbrown, whereas other selections of this species have bright green coppiced stems. This cultivar is suitable for living structures, hedges, shelter belts, and coarse basketry. 'Arnold Select' is hardy to at least USDA Zone 4. Dodge received this plant from the Arnold Arboretum in Boston, MA.

'Bronze Beauty'. A female clone of $S$. myricoides Muhl., or possibly a hybrid of this species, suitable for gardens. It is more vigorous than the species and has larger bronze-colored new leaves. 'Bronze Beauty' was discovered by Dodge as a branch sport on a plant from Wisconsin, and it was propagated in 2014.

'Filigree'. A male clone of $S$. interior Rowlee, distinguished by very long and slender green foliage. This selection is very ornamental and can be used for basketry, phytoremediation, and erosion control because it spreads widely by underground stems. It is hardy to USDA Zone 3. Dodge discovered this plant near a pathway in Tennessee in 2016.

Received for publication 10 Aug. 2020. Accepted for publication 28 Oct. 2020.

Published online 24 November 2020

Y.A.K. is the corresponding author. E-mail: jkuzovkina@ uconn.edu.

This is an open access article distributed under the CC BY-NC-ND license (https://creativecommons. org/licenses/by-nc-nd/4.0/).
Zone 3. It can be used for ornamental purposes and fine basketry.

'Violet Beauty'. A vigorous female clone of $S$. irrorata Andersson with deep violet stems, covered with white bloom, and bright red buds and leaf petioles. Dodge received this plant from the Chicago Botanic Garden and named it in 2016. It is suitable for gardening, living structures, and basketry.

'Winter Glory'. A vigorous male clone of $S$. Xleucopithecia Kimura with upright arching stems and large red buds. The fully expanded catkins, which reach up to 5 to $8 \mathrm{~cm}$ long, are very ornamental and are frequently used for floral cut-stems. Original plants were procured from Spring Meadow Nursery in Michigan as $S$. chaenomeloides Kimura (Kuzovkina et al., 2016). It is hardy to USDA Zone 4.

'Winter Green'. A vigorous male clone of $S$. miyabeana Seemen with bright green stems. Dodge received this plant from a basket grower; it is likely that the plant originated at the willow breeding program at the University of Toronto, Canada. It is one of the best selections for basketry, living fences, and structures.

The following two cultivars were registered 15 July 2020 by Yulia Kuzovkina; University of Connecticut, Storrs, CT.

'Alexander'. A male hybrid of S. rosmarinifolia $\mathrm{L} . \times S$. viminalis $\mathrm{L}$. developed by Vladimir Sukachev in Russia during the 1930s. It is a shrub with a dense crown, thin stems, and bright buds. 'Alexander' is very ornamental in spring, when covered with abundant golden catkins. Etymology: It is named in recognition of Alexander Marchenko, a Russian salicologist who preserved this plant in his garden.

'Rabbit's Foot'. A vigorous male clone of $S$. ×leucopithecia Kimura. Its large catkins have aberrations in the form of lumps, which resemble a rabbit's foot in size and structure. Original plants were procured from Klyn Nurseries, OH, in 1999, as $S$. chaenomeloides Kimura (Kuzovkina et al., 2016).

The following 13 cultivars were registered 4 Dec. 2018, by Alexander M. Marchenko; Water Plants Nursery, Pushkino, Moscow region, Russia. The crosses of these cold-hardy ornamental hybrids were made by Veniamin I. Shaburov in Yekaterinburg, Russia, in the $1960 \mathrm{~s}$ and 1970s, and described by Marchenko $(2017,2019)$. The standard herbarium specimens for these cultivars are stored at the Royal Horticultural Society (WSY), US National Arboretum (USNA), and Main Botanical Garden, Russia (MHA).

'Lyubimecz'. A male hybrid of S. alba L. $\times S$. fragilis, up to $18 \mathrm{~m}$ in height with a pyramidal crown, slightly pendulous bright orange branchlets, and ornamental flowers. Etymology: 'Lyubimecz' means "a favorite" in Russian.

'Oranzhevaya Tolstostvol'naya'. A robust female hybrid of $S$. alba $\times S$. fragilis, up to $16 \mathrm{~m}$ in height with yellow stems, becoming reddish brown at the tips. The elongated orange crown becomes weeping after 10 years. Etymology: 'Oranzhevaya Tolstostvol'naya' 
means "an orange thick-stemmed" in Russian.

'Oranzhevaya Tonkostvol'naya'. A female hybrid of $S$. alba $\times S$. fragilis with thin yellow-orange stems, similar to 'Lyubimetz', but with a wider crown. Younger trees have a pyramidal crown, which becomes weeping at the age of 5 to 8 years. Etymology: 'Oranzhevaya Tonkostvol'naya' means "an orange thin-stemmed" in Russian.

'Pamyati Shaburova'. A male hybrid of S. babylonica $\times S$. ×pendulina Wender. with oval crown and strongly pendulous branches. 'Pamyati Shaburova' is a cold-hardy weeping willow suitable for cultivation in northern regions. Etymology: 'Pamyati Shaburova' means "in memory of Shaburov" in Russian. Shaburov was a willow breeder in Yekaterinburg, Russia.

'Permyachka'. A female hybrid of $S$. schwerinii E. L. Wolf with an unknown Salix. This is an ornamental tree up to $8 \mathrm{~m}$ tall, with a wide pendulous crown $10 \mathrm{~m}$ in diameter. It has long and narrow leathery leaves with silver-green undersides. Etymology: 'Permyachka' means "a woman from Perm" in Russian.

'Podarok Sud'by''. A hybrid of $S$. babylonica $\times S . \times$ pendulina 'Elegantissima' reaching $12 \mathrm{~m}$ in height. It is a green-barked weeping tree with a broad crown and cascading branches. Foliage is green above with glaucous undersides, which makes the leaves appear bicolored at a distance, even on a calm day. Catkins are mostly androgynous. Etymology: 'Podarok Sud"by" means "destiny's gift" in Russian.

'Rekord Krasnoseryozhchaty'j'. A fastgrowing male hybrid of $S$. schwerinii E. L. Wolf $\times S$. gmelinii Pall. with a pyramidal crown and pendulous stems. Branchlets are olive green, with long pendulous leaves. Flower bracts change their color from yellow to red, and later become black. Etymology: 'Rekord Krasnoseryozhchaty'j' means "a red-catkin record" in Russian.

'Strela Kupidona'. A male hybrid of $S$. alba $\times S$. fragilis with a narrow, pyramidal, dense crown and bright orange stems. 'Strela Kupidona' resembles $S$. alba 'Liempde' but has brighter stems and is very cold hardy. Etymology: 'Strela Kupidona' means " $\mathrm{Cu}$ pid's arrow" in Russian.

'Teatral'naya'. A female hybrid of $S$. pentandra $\mathrm{L} . \times S$. fragilis with multiple trunks, green branchlets, and lustrous dark green leaves. Etymology: 'Teatral'naya' means "theatrical" in Russian. It was discovered by Marchenko in willow plantings in front of Perm's Theater in Russia.

'Unikal'naya'. A fast-growing male hybrid of $S$. schwerinii $\times S$. gmelinii. It has an attractive, broad, pendulous crown, yellow bark, and long bicolored leaves. Etymology: 'Unikal'naya' means "unique" in Russian.

'Ural'skaya Izvilistaya Parkovaya'. A contorted female hybrid of $S$. babylonica $\times S$. fragilis. This is a very robust tree up to $16 \mathrm{~m}$ in height. It is recommended for urban parks and streetscaping. Its numerous green catkins intensify the foliage color in spring. Etymology: 'Ural'skaya Izvilistaya Parkovaya' means "Ural's contorted park" in Russian.

'Ural'skaya Izvilistaya Uzkopiramidal'naya'. A contorted male hybrid of $S$. babylonica $\times S$. fragilis up to $11 \mathrm{~m}$ in height, with narrow, pyramidal crown, green branches, and golden brown buds. Unfolding leaves are red, which distinguishes this cultivar from other contorted hybrids. Etymology:
'Ural'skaya Izvilistaya Uzkopiramidal'naya' means "Ural's contorted narrow-pyramidal" in Russian.

'Xmelyovskaya Blestyashhaya'. A male hybrid of $S$. pentandra L. $\times S$. fragilis L. up to 7 to $8 \mathrm{~m}$ in height with shiny, light brown green branchlets, and almost black buds. Leaves are lustrous dark green above, with glaucous undersides. Large bright yellow catkins, which appear with leaves, are fragrant and ornamental. Etymology: 'Xmelyovskaya Blestyashhaya' means "Xmelyovsk's lustrous" in Russian. Xmely is the name of the village near the city of Perm in Russia, where this cultivar was planted.

\section{Literature Cited}

International Register of Cultivars of Salix L. (Willow). 2020. 2 Nov. 2020. <https://osf.io/ $45 \mathrm{tkg} />$.

Kuzovkina, Y.A. 2015a. Compilation of the checklist for cultivars of Salix L. (willow). HortScience 50(1):1608-1609.

Kuzovkina, Y.A. 2015b. Checklist for cultivars of Salix L. (willow). 2 Nov. 2020 $<\mathrm{http}$ ://www.fao.org/forestry/440580370ab0c9786d954da03a15a8dd4721ed.pdf>.

Kuzovkina, Y.A. and L. Vietto. 2014. An update on the cultivar registration of Populus and Salix (Salicaceae). Skvortsovia 1:133-148.

Kuzovkina, Y.A., M. Dodge, and I.V. Belyaeva. 2016. Clarifying affiliations of Salix graciclistyla Miq. cultivars and hybrids. HortScience 51(4):334-341.

Marchenko, A.M. 2017. V.I. Shaburov's ornamental hybrid willows for northern climates [Russian]. Non-Stop, Moscow, Russia.

Marchenko, A.M. 2019. Ovules and identification of willows (Salix) [Russian]. Non-Stop, Moscow, Russia.

Vermont Willow Nursery. 2020. 5 Aug. 2020.<https:// www.willowsvermont.com/varieties.html $>$. 